\title{
Kraina wiecznego szczęścia
}

Recenzja książki: Karolina Kostyra, Wiosenna bujność traw. Obrazy przyrody w filmach o dorastaniu, Wydawnictwo Uniwersytetu Śląskiego, Katowice 2019, s. 184. Oprawa miękka, publikacja polskojęzyczna.

Niektóre filmowe motywy mocno zakorzeniły się w naszej świadomości. Skrojone pod prywatne wspomnienia, tęsknoty i marzenia, pod egzystencjalne obawy i życiowe oczekiwania, wydają się mieć tysiące ekranowych manifestacji. Myśląc o nich, nie potrafimy czasem wskazać choćby jednego, konkretnego tytułu, ale mamy wrażenie, że „myślana” właśnie opowieść prezentowałaby się nadzwyczaj dobrze, gdyby zapisać ją na celuloidzie. Czasem chwytamy w pamięci mgliste wspomnienia podobnych fabuł albo błędnie przypisujemy je najróżniejszym historiom. Potrafimy jednak wyobrazić je sobie tak, jakby stanowiły rdzeń niejednego filmu.

Znamy przecież dobrze „tego” mężczyznę w średnim wieku, krzątającego się w swojej domowej pracowni fotograficznej. Kiedy go obserwujemy, zdajemy sobie sprawę, że wszystko, co otacza bohatera, jest oświetlone anemicznymi błękitami, prezentuje się ponuro i nieprzyjaźnie. Sam protagonista też sprawia wrażenie zszarzałego pod wpływem smutku. Ciszę w tym zawodowym sanktuarium przerywa dzwonek u drzwi. Mężczyzna odbiera od kuriera przesyłkę, której zawartość za chwilę przypomni mu minione czasy. Zaczyna się boleśnie: z paczki wysuwa się zawiadomienie o śmierci przyjaciela $\mathrm{z}$ dzieciństwa. W kartonie znajduje się też prawdziwy skarb - należąca do starego kumpla sfatygowana rękawica baseballowa. Czule pogładzony artefakt okazuje się pretekstem do odbycia podróży w czasie. Fotograf reaguje refleksyjnym impulsem: „Pamięć może nas dopaść w każdej chwili. I nie wiadomo dokąd nas zabierze. Można tylko liczyć, że w jakieś przyjemne miejsce". Później, w fizycznym wymiarze, mężczyzna znajdzie się na pogrzebie dawnego kompana, jednak pod względem emocjonalnym rozpocznie się jego wędrówka w czasie - poprzez jedyny, „prawdziwy” świat wspomnień z dzieciństwa.

Bohater tego szkicu fabularnego (opartego na opowiadaniu Stephena Kinga) przenosi się do Krainy wiecznego szczęścia (reż. Scott Hicks, USA 2001). Zagłębia się w echach dawnych przeżyć - wyjątkowych chwilach "tych” letnich wakacji, kiedy wydarzyło się coś ważnego. Początkowo nurza się we wspomnieniach 
jakby na ślepo, ale po chwili odnajduje właściwą drogę. W mgnieniu oka, już jako młody Bobby Garfield, pojawia się w tunelu kanalizacyjnym, u którego wylotu mienią się świeżą zielenią okazałe lasy. Obok bohatera kroczą jego towarzysze zabaw. Młodzi bohaterowie wędrują przez nieużytki i dzielą się niewybrednymi żartami. To zaproszenie do opowieści o zdarzeniach, które odmieniły życie jedenastoletniego chłopca i sprawiły, że „to” właśnie lato okazało się ostatnim beztroskim latem jego życia (lub, jak po prostu powie Garfield, ostatnim latem jego dzieciństwa).

Dla fotografa $\mathrm{z}$ ponurej pracowni rękawica baseballowa stanowi przesłankę do wzięcia udziału w sentymentalnej podróży. Taka jest siła przedmiotów - nośników wspomnień. Osobiste rzeczy, niczym za dotknięciem czarodziejskiej różdżki, rozświetlają twarz nostalgika, łącząc strzępy wspomnień w spójną narrację o minionych zdarzeniach. O mocy przedmiotów przekonuje się bohater Zielonej doliny (reż. John Ford, USA 1941), który w prologu zwierza się z zamiaru opuszczenia rodzinnej miejscowości. Kiedy Morgan pakuje rzeczy w sfatygowaną chustę matki, nachodzi go refleksja: „Opuszczam moją dolinę. Tym razem już do niej nie wrócę. Zostawiam za sobą 50 lat wspomnień”. Po chwili przenosi się do czasów dzieciństwa, do „swojej” doliny - rozległej, zielonej i najwspanialszej, bo w końcu, jak deklaruje, „w całej Walii nie było piękniejszego miejsca”.

Przedmioty często prowadzą swoich właścicieli w pozornie zapomniane miejsca, które niegdyś wcale nie uznawane za nadzwyczajne, po latach uwodzą wyjątkową urodą i spokojem. Dawno temu w tych przestrzeniach dokonywały się rzeczy fundamentalne, z których podniosłości dorastający młodzi ludzie zwyczajnie nie zdawali sobie sprawy, lecz które w oczywisty sposób odciskały kształt na adolescentach. Cyklicznie wraca w świadomości pamięć „tamtych” miejsc i zdarzeń. „Tymi” miejscami mogą być oczywiście szkolne boiska, salony gier, centra handlowe albo pobliskie złomowiska, ale „miejskość” rzadko kiedy jest tak barwna i nęcąca jak otaczające miasteczka lasy, tajemnicze zagajniki, górskie chatki i ukryte gdzieś w gąszczach roślinności jeziora. Przyroda bowiem, jak przekonuje Karolina Kostyra, autorka książki Wiosenna bujność traw. Obrazy przyrody w filmach o dorastaniu, w sposób szczególny oddziałuje na dorastających ludzi. Tylko w czasie dojrzewania jest tak płodna i ekspansywna, że porywa w swoje głębie i na zawsze odmienia młodego człowieka, przygotowując go do podjęcia dorosłego życia (s. 13-15).

Przykład rękawicy baseballowej z Krainy wiecznego szczęścia przypomina o jeszcze jednej narracji, w której ten amerykański symbol niedorosłości staje się pretekstem do wglądu w przeszłość. Kiedy bohater Buszującego w zbożu, osławionej powieści Jerome’a Davida Salingera, po raz pierwszy rozważa naturę wspomnień, spisuje właśnie historię rękawicy należącej do nieżyjącego już brata. Najważniejszą myśl Holden wykłada jednak w zwieńczeniu swoich losów: „Lepiej 
nigdy nikomu nic nie opowiadajcie. Bo jak opowiecie - zaczniecie tęsknić”. W tym smutnym spostrzeżeniu nie ma jednak choćby odrobiny żalu - tylko ciepłe skojarzenia i wszechogarniająca tęsknota za dawno nie widzianym domem, miejscem - korzystając ze słownika Bachelarda - „absolutnej intymności”. Podobna tęsknota wyziera z książki Karoliny Kostyry, która już we wstępie zwraca uwagę na charakter resentymentu młodości: „Wiosenna bujność traw prawdziwie zieleni się tylko we wspomnieniu" (s. 13).

W Wiosennej bujności traw autorka zaprasza na intelektualne buszowanie po ekranowych lasach, okraszone filmową erudycją i kompetencjami interpretacyjnymi, a przy tym nasycone sporymi pokładami wrażliwości. Na tle stonowanego modelu uprawiania filmoznawstwa na gruncie polskim książka Kostyry prezentuje się niezwykle. Osobista i emocjonalnie zaangażowana refleksja oraz melancholijny ton książki ściśle korespondują z tematyką podejmowaną $\mathrm{w}$ filmach o dorastaniu. Tęsknota płynie więc tutaj zarówno z przeżyć bohaterów, jak i z poszukiwań autorki, żywo zaangażowanej w relacjonowanie opowieści o pograniczu dzieciństwa i dorosłości - najpiękniejszym (trudno odnieść inne wrażenie po lekturze książki) czasie naszego życia. Autorka zdaje się przy tym przekonywać, że nie trzeba rugować z życia pierwiastka ocalonej dziecięcości należy raczej pielęgnować w sobie młodzieńczą pasję odkrywania świata.

Jak stwierdził kiedyś Zygmunt Bauman, „człowiek jest najbardziej ludzki w dzieciństwie (żyje wtedy w świecie pełnym możliwości jeszcze niezamkniętych ani niezdyskredytowanych, kuszących nieodgadnieniem tajemnic, przyszłości bez granic), ale za znamię dojrzałości uważa odejście od dzieciństwa i trawi swe wysiłki na to, by dzieckiem być przestać" ${ }^{2}$. Kostyra przygląda się filmowemu gatunkowi coming of age i towarzyszy młodym bohaterom, by opowiedzieć o czasie tych szczególnych przemian. Czasie słodkim i okrutnym jednocześnie, kiedy w powietrzu czuć zapowiedź nadchodzących zmian. I choć adolescenci nie potrafią jeszcze stwierdzić, na czym miałyby one polegać, to snują już przypuszczenia, że ich dzieciństwo nieubłaganie się kończy.

W Czarnoksiężniku z Oz (reż. Victor Fleming, USA 1939) Dorotka zgadza się z opinią wróżbity: „Rodzina Cię nie rozumie, nie docenia. Chcesz zobaczyć inne kraje, wielkie miasta, góry, oceany”. W realiach amerykańskiego wielkiego kryzysu dziewczynka przeżywa prawdopodobnie swoje ostatnie, marzycielskie chwile w otoczeniu przyrody, tuż przed bolesnym końcem dzieciństwa. W Moście

1. Gaston Bachelard, Ziemia, spoczynek, marzenia, w: Gaston Bachelard, Wyobraźnia poetycka. Wybór pism, przeł. Henryk Chudak, Anna Tatarkiewicz, Państwowy Instytut Wydawniczy, Warszawa 1975, s. 301.

2. Zygmunt Bauman, Ponowoczesność jako źródło cierpień, Wydawnictwo Sic! Warszawa 2013, s. 213. 
do Terabithii (reż. Gabor Csupo, USA 2007) przykre tony wybrzmiewają jeszcze wyraźniej, kiedy ojciec głównego bohatera zaczyna gorliwie przysposabiać syna do dorosłości. Coraz mniej między nimi bliskości, a coraz więcej rozmów o ekonomicznych problemach dorosłych, którymi niby przypadkiem, ale zaskakująco często, obarcza się dorastającego chłopca - stopniowo odbierając mu niewinność spojrzenia. Bohaterowie obu filmowych baśni oddalą się wkrótce od zaczarowanych światów, by realizować swoje społeczne powinności. Kostyra śledzi podobne tropy i analizuje postawy młodych bohaterów, którzy stopniowo wkraczają w poważny i zszarzały świat dorosłych. Niektórzy z nich zmagają się ze śmiercią (Stań przy mnie, reż. Rob Reiner, USA 1986), inni z rodzącą się w nich seksualnością (Walkabout, reż. Nicolas Roeg, Australia, Wielka Brytania 1971), a jeszcze inni nie mogą dojść do ładu z samym sobą po zawodzie miłosnym (w rozdziale poświęconym letniskom jest kilku takich nieszczęśników), wszyscy jednak przeżywają bolesny rozbrat z żywymi, pulsującymi i oddychającymi cudami przyrody.

Celem Karoliny Kostyry jest nie tyle rekapitulacja czy leksykonowe opracowanie tematyki filmów coming of age (s. 7-8), ile refleksja nad szczególnym momentem życia każdego człowieka, naznaczonym bliską więzią i współodczuwaniem z przyrodą. W omawianych przez autorkę filmach cudowna natura, owa Wielka Matka, bywa zagrożeniem, ale roztacza też troskliwą opiekę nad swoimi dziećmi. Filmoznawcza publikacja przybiera więc momentami kształt ogólnohumanistycznej refleksji nad światem i miejscem człowieka (bynajmniej nie centralnym) w tym rozległym porządku. Istotę związku między człowiekiem i przyrodą autorka próbuje zgłębić, sięgając do różnych źródeł - poszukuje tropów w Jungowskiej krytyce mitograficznej, przywołuje rozpoznane przez Mirceę Eliadego motywy symboliki magiczno-religijnej, zaś za Bruno Bettelheimem rozpatruje eksternalizującą funkcję baśni. Z tym bagażem teoretyczno-kulturowym Kostyra przygląda się między innymi scenie łapczywego pożerania owoców w Walkabout, obrazowi pijawek wsysających się w bohatera Stań przy mnie i lunarnej symbolice wilgotnych obiektów z Zepsutego owocu (reż. Kô Nakahira, Japonia 1956), by ustalić ostatecznie miejsce człowieka w cyklu życia.

Autorka Wiosennej bujności traw czule przygląda się przyrodzie, podobnie jak bohaterowie analizowanych przez nią filmów: młodzi ludzie, którzy w przededniu dorosłości są jeszcze wrażliwi na widoki bujnych lasów, zwierzęcych przepychanek, niesamowitych skalnych występów i wartkich potoków. Nastolatków niewiele już jednak dzieli od rozstania $\mathrm{z}$ naturą. Wielu z nich ponowi przecież los Mietka z filmu Płyną tratwy (reż. Władysław Ślesicki, Polska 1962), który - wkraczając w świat dorosłości - stopniowo zatraca łączność z przyrodą (s. 67-73). W tym kluczowym momencie życia charakter związków z Wielką Matką na zawsze się odmienia. 
Książka Karoliny Kostyry jest daleka od protekcjonalności - nasycona wrażliwością, tęsknotą i zrozumieniem, wydaje się pozytywnie odmienna od obecnych na polskim gruncie filmoznawczym niezgrabnych prób rozpoznania gatunku coming of age. W odróżnieniu od siermiężnej refleksji nad „kinem dla dzieci i młodzieży", rozważania Kostyry rozbudzają pasję i przypominają, że obrazki z przeszłości, które po latach często „widzimy” w zabarwieniu sepii, mają swoje wspaniałe, żywe kolory. Kiedy odwiedza się dawne miejsca zabaw, to nierzadko przyroda wydaje się dużo mniej imponująca niż w czasie adolescencji (jak w filmie Nad rzeką, której nie ma, reż. Andrzej Barański, Polska 1991, s. 146-147). By odzyskać kształt dawnych okolic nie wystarczy do nich fizycznie powrócić najważniejsza jest zmiana perspektywy. Dzięki Wiosennej bujności traw dziecięce wspomnienia ponownie sycą się barwami.

Autorkę interesują formy manifestowania się przyrody w kinie coming of age, gdyż właśnie w asyście natury młodzi bohaterowie zmierzają ku dorosłości. Tak jak filmy o dorastaniu są oknem pozwalającym spojrzeć w nastoletnią przeszłość, tak też książka Karoliny Kostyry daje wgląd we wspólnotowe doświadczenie, przybierające jednak swój indywidualny kształt w każdym, jednostkowym przypadku. Znawczyni filmów inicjacyjnych zabiera czytelnika w podróż po magicznych miejscach, o których urokach być może już zapomnieliśmy. Koncentruje się na losach niemądrych nastolatków, lecz czasem przygląda się też dorosłym bohaterom, którzy z rozrzewnieniem wracają do przeżyć z dzieciństwa. Wraz $\mathrm{z}$ nimi prowadzi poszukiwania niemal $\mathrm{w}$ duchu Colette, która ubolewała nad utraconą więzią: „Ten dom i ten ogród istnieją jeszcze, ja wiem, ale cóż z tego, skoro straciły już swoją siłę magiczną, skoro zaginął sekret otwierający przede mną tamten świat - blaski, wonie, harmonię drzew i ptaków, szmer głosów uciszony już przez śmierć - tamten świat, którego przestałam być godna”3. Choć nazwisko autorki Domu Klaudyny nie pada w książce Kostyry, to filmoznawczyni odznacza się podobną wrażliwością co francuska pisarka. Obie z czułością przyglądają się owemu światu „powszednich rzeczy cudownych”": uwodzicielskich źródeł i nęcących zagajników, wprost jakby wyjętych z twórczości Williama Butlera Yeatsa. Kiedy wraz ze swoimi protagonistami autorka Wiosennej bujności traw przygląda się cudownym pejzażom, jest na moment jak Sido, zastanawiająca się, czy całą tę wspaniałość przyrody - ukryte strumienie i jagodowe gęstowia - „widziało i widzi wciąż jeszcze naiwne uszczęśliwienie mojego serca, czy też widziały ją moje olśnione oczy”.

3. Sidonie-Gabrielle Colette, Dom Klaudyny, w: Sidonie-Gabrielle Colette, Dom Klaudyny, przeł. Krystyna Dolatowska, Państwowy Instytut Wydawniczy, Warszawa 1988, s. 10.

4. Sidonie-Gabrielle Colette, Sido, w: Sidonie-Gabrielle Colette, Dom Klaudyny..., s. 153.

5. Colette, Sido..., s. 151. 
Karolina Kostyra przychodzi z pomocą czytelnikowi i przypomina mu o sile dziecięcej wrażliwości. Wzorem Yeatsa, który w Skradzionym dziecku przydawał realnie istniejącym irlandzkim wyżynom mityczny charakter, autorka Wiosennej bujności traw odkrywa na nowo uroki dawnych miejsc: do bólu przecież zwyczajnych, lecz jednocześnie oszałamiająco nadzwyczajnych. Buszuje w sensualnych gęstwinach Dancingu w kwaterze Hitlera (reż. Jan Batory, Polska 1968) i włóczy się po lasach w Nad rzeką, której nie ma, maszeruje najeżonymi niebezpieczeństwami duktami z bohaterami Stań przy mnie i nurkuje w migoczących refleksami jeziorkach z Walkabout, odwiedza wreszcie „wzniosłe” ruiny z filmu Zapamiętajmy to lato (reż. Siergiej Sołowjow, ZSRR 1974), mocno już zarośnięte pędami, które za nic mają zabytkowe statusy ludzkich dzieł. Przyglądając się tym miejscom dziecięcych przygód i rozpatrując ich znaczenie dla dorastania, autorka tłumaczy przebyte próby inicjacyjne poprzez dwie kategorie, którym symbolicznie patronują dwie figury: szałasów i letnisk.

Po pierwsze Kostyra analizuje więc miejsca nieujarzmione i niezbadane, w których się nie osiedla, lecz które się przemierza. Protagoniści filmów o dorastaniu są w drodze, bo ruch związany jest z procesualnością samej młodości (s. 12). Sięgając do mitów i religioznawczych analiz, autorka dostrzega paralele między losem swoich wędrujących bohaterów i przebiegiem obrzędów inicjacyjnych. W części „Szałasy” filmoznawczyni towarzyszy zatem młodym ludziom, których rites of passage dokonują się właśnie w trakcie podróży przez nieujarzmiony świat natury. Przyroda stale towarzyszy bohaterom: stymuluje tę wędrówkę (s. 44), kieruje nią (czasem upersonifikowana w postaci Aborygena z Walkabout, s. 61), a ostatecznie prowokuje przemianę młodych protagonistów - wtajemniczając ich w prawdziwe życie (s. 26).

Analizowane przez autorkę manifestacje owego „wyjścia z wieku” dziecięcego (s. 27) mocno się od siebie różnią. O ich ostatecznym kształcie decydują kluczowe kwestie - miejsce, czas i motywy podjęcia wędrówki. W końcu, jak zauważa Kostyra, niełatwo zgubić się w lesie w dobie technik GPS, więc we współczesnych filmach coming of age - jak uczą Królowie lata (reż. Jordan Vogt-Roberts, USA 2013) - trzeba chcieć się zgubić, by przeżyć tę życiową przygodę (s. 39). Nie mniej istotną rolę w portretowaniu rytuału przejścia odgrywają społeczno-kulturowe sposoby ujmowania płci. Sam fakt oddalenia się od domu, doznania niewygód i późniejszej „transformacji jakościowej osobowości” (s. 27) jest oczywiście wspólny dla filmowych chłopców i dziewcząt. Jednakże w kulturze patriarchalnej ekranowe motywacje młodych mężczyzn są zwykle dużo bardziej ekscytujące już w samych zamiarach (s. 47-48) - dorastające dziewczynki trafiają przecież w dzicz podczas zupełnie niespontanicznych pikników. Mimo to, miastowe panienki radzą sobie później nie gorzej niż ich chłopięcy rówieśnicy. Bohaterki i bohaterów omawia- 
nych przez autorkę filmów łączy to, że jako inicjanci symbolicznie giną podczas podejmowanych podróży i podczas nich się odradzają (s. 22-23).

Protagoniści doświadczają więc w podróży fundamentalnego przeobrażenia: opuszczają domy jako dzieci, by później do nich wrócić jako osoby dorosłe. Paradoksalnie, właśnie podczas tej wędrówki młodzi ludzie muszą nauczyć się obcowania z naturą. Zdobycze cywilizacyjne: dobre maniery, szkolna wiedza czy nawet znajomość języka (Walkabout) wyłącznie spowalniają przebieg rytuału przejścia. Miejsce wyuczonych wzorów kulturowych zajmuje w świecie przyrody obeznanie w jej tajemnych kodach oraz znawstwo fauny i flory (s. 74). W końcu, jak przekonuje autorka, by przeżyć przemianę, trzeba się wcześniej przejrzeć w lustrze natury (s. 71).

Jak pisze Kostyra, przyroda przypomina swoim podopiecznym o „przemijalności życia [...], pozwala się usamodzielnić i wypróbować pierwotne instynkty, bez zażenowania ujawnia swą naturalną sensualność i wreszcie - nawołując w duchu kantowskiej wzniosłości o moralnej powinności człowieka - ulega jego cywilizacyjnym przekształceniom" (s. 74). Koniec każdej dziecięcej przygody jest więc tak przygnębiający, jak widok augustowskiej puszczy wyrębywanej przez drwali w filmie Plyna tratwy (s. 72). Bohaterowie odbierają od natury naukę, a po zwieńczeniu swoich zmagań stopniowo oddalają się od niej - uświadamiają sobie, „jakimi rzeczy są naprawdę" (s. 33). Przyroda traci wtedy swój fascynujący kształt, a młodzi dorośli odpalają papierosy (Płyna tratwy, s. 73) i wracają do miasta samochodami (Królowie lata, s. 47). Aborygen przestaje być potrzebny mieszczuchom (s. 64), a ptak, którym Mietek dawno temu z pewnością by się zaopiekował, nie potrafi znaleźć dla siebie lądowiska w wykarczowanym lesie (s. 73). Obezwładniające poczucie utraty tknie bohaterów później - kiedy „powrót” do świata nieskażonego oszustwem dorosłości nie będzie już możliwy.

Nie jest to rzecz jasna narracja wyłącznie filmowa. Ciekawe, że choć każdy $\mathrm{z}$ nas dysponuje odmiennymi wspomnieniami z czasów dojrzewania, to w gruncie rzeczy istnieje w tym aspekcie pewna wspólnota pamięci. Dawne, wydawałoby się, że spektakularne, wędrówki wyglądają dziś blado - włóczęgi według map wyznaczanych przez rury systemów ciepłowniczych wydają się szczenięcą głupotą, a los kolegi zranionego wełną szklaną nie jest w ułamku nawet tak emocjonujący, jak się niegdyś wydawało. Jednak pod wpływem Wiosennej bujności traw nawet te, niezbyt imponujące, naznaczone śląskim krajobrazem wspomnienia, zyskują swój urok. Choć dotyczą miejsc odległych od rozległych lasów i dzikich zagajników, przejrzystych jezior i szumiących wodospadów, to i one wydają się piękne, bo przecież, jak pisała Margaret Wolfe Hungerford w Molly Bawn, „piękno jest w oku obserwatora".

Po drugie Karolina Kostyra mierzy się z miejscami bardziej uporządkowanymi, przypominającymi parki i ogrody (s. 18), których się nie pokonuje, lecz w których 
jest się przez przyrodę okalanym. Letniska sugerują inną strategię kontaktu z przyrodą - zorientowaną nie na przekraczanie i poskramianie, lecz poddawanie się jej wpływowi w chwilach próżnowania i odpoczynku (s. 79). Jak zauważa Kostyra, jest taka chwila w ciągu roku, która pozwala oddać się owemu rozkosznemu nicnierobieniu - wakacje. To kluczowy czas, dający wytchnienie od nasyconego najróżniejszymi zajęciami żywota młodego człowieka. „Nieprzerwana letnia idylla bogata w sensualne przyjemności, wolna od zobowiązań" (s. 80) jest przez nastolatka nerwowo wyczekiwana. Zwłaszcza pierwszy dzień wakacji stanowi zapowiedź nadchodzących, ekscytujących doznań (por. s. 79). Letnia przerwa jest oczywiście uznawana przez młodzież za odskocznię od zwyczajności (s. 84), ale wiąże się z nią także, dużo bardziej stresujące, antycypowanie nadchodzących przygód miłosnych. Zmysłowym uniesieniom można oddać się bezgranicznie właśnie podczas wakacyjnych wyjazdów - z dala od domu, blisko rozbudzonej, bujnej przyrody (s. 80).

$\mathrm{Na}$ letniskach natura jest gotowa na przybycie spragnionych sensualnych doznań młodych ludzi. Niedoświadczonych bohaterów okala atmosfera rozluźnienia norm, kurorty kuszą atrakcjami, a przyroda zaprasza do wkroczenia w przestrzeń, w której wszystko rozrasta się i wydaje obfite plony. Letniska są miejscami szczególnymi, w których rygor regulaminów splata się ze zwolnieniem $\mathrm{z}$ zasad, a natura rywalizuje o prymat przestrzenny $\mathrm{z}$ obiektami wzniesionymi przez człowieka. Nie ma jednak w tych realiach twardych opozycji - wszędzie mnożą się przejścia, korytarze i portale (s. 86), które otwierają przed bohaterami „pola nieograniczonych możliwości” (s. 97).

Męscy bohaterowie filmów o dorastaniu beztrosko oddają się wakacyjnym przyjemnościom - kąpią się w morzu, odpoczywają w słońcu, włóczą się z kumplami, piją wino i obscenicznie żartują, lecz... jedynie do czasu. Kiedy rozkwita przyroda, ożywiają się także młodzi ludzie: nadchodzi czas, jak zwraca uwagę Kostyra, na „wyładowanie nadmiaru energii seksualnej, przebudzenie zmysłów, a przede wszystkim wznoszenie się ku swobodzie jako takiej" (s. 103). O ile więc w "Szałasach” pleniąca się przyroda wymagała od młodych bohaterów dynamizmu i podjęcia fizycznej eskapady w głąb natury, o tyle w „Letniskach” budzące się do życia zieloności katalizują wybuchy miłosnych namiętności. Jak przekonuje autorka, w tych narracjach impuls uczuciowy pochodzi z natury. Niezależnie od tego, czy chodzi o upały, które porażają młodych pionierów z Zapamiętajmy to lato, czy o podmiejską sielankę i śpiew słowika, sprzyjające zbliżeniu w Wycieczce na wieś (reż. Jean Renoir, Francja 1936), albo o mazurskie zalesienia, przesłaniające sylwetkę ślicznej dziewczyny z Dancingu w kwaterze Hitlera, przyroda wyraźnie roznamiętnia bohaterów.

W wakacyjnej scenerii bohaterowie poszukują możliwości spełnienia swoich pragnień, jednak rzadko kiedy podejmowane przez nich próby kończą się osią- 
gnięciem satysfakcji. W „Letniskach” Kostyra opowiada o trudach seksualnych inicjacji i miłosnych rozczarowaniach (s. 80). Zaaferowana, młodzieńcza pasja nie wystarcza przecież, kiedy w grę wchodzą pułapki dziewczęco-chłopięcych relacji. Letnie zauroczenie kończy się zwykle zawodem i dojmującym poczuciem niesprawiedliwości. Czasem nie wystarczy poczekać „aż minie wstyd”, jak w Dancingu w kwaterze Hitlera (s. 110). Gorzki jest finał Wycieczki na wieś, w której nieszczęśliwi bohaterowie zmagają się już wyłącznie z postępującą martwotą. Gdzie szukać winnych doświadczonych niepowodzeń i doznanych upokorzeń, jeśli nie w prowokującym całe to zamieszanie świecie przyrody? Na naturę trudno się jednak wściekać - chyba że przybiera ona akurat postać uwodzicielskiej kobiety-węża z filmu Jana Batorego (s. 113-116) lub wabiącej naiwnych mężczyzn „księżniczki o rybim zapachu” z Zepsutego owocu (por. s. 124). Mityczne i archetypiczne konotacje obu stworzeń przypominają ambiwalencję bolesnego przebudzenia nastoletniej seksualności z baśni Śniący chłopcy Oskara Kokoschki, która mogłaby przecież patronować Wiosennej bujności traw. W 1907 roku ze zderzenia świadomości z nieświadomością powstała narracja pograniczna - halucynacyjna, bo łącząca bolączki realności i perwersje sennych fantazji. $\mathrm{W}$ onirycznym dziele austriackiego grafika, podobnie jak w omawianych przez Kostyrę filmach o dorastaniu, zielone krainy są zamieszkane przez stwory, piękno płynnie przenika się z brzydotą, a satysfakcja $\mathrm{z}$ cierpieniem ${ }^{6}$.

W okresie dorastania żadne przestrogi nie trafiają jednak do małoletnich - bohaterowie, przeczuwając zbliżającą się dorosłość, żyją ze wszystkich sił i zakochują się na zabój. Niczym oszalali, fantazjują o swoich ukochanych, ale ostatecznie okazują się bezradni - jak przystało na dorastających młodych ludzi. Pozostaje im rzucanie zazdrosnych spojrzeń na obiekty zainteresowania swoich sympatii. Protagoniści nie zyskują emocjonalnego spełnienia, ale wydaje się, że nie wracają z wakacji z pustymi rękami. Jak wspominał bohater Krainy wiecznego szczęścia: "Otworzyły mi oczy na przyszłość". Kiedy lato się kończy, trzeba żyć dalej - zaakceptować swoje porażki i zapomnieć o kompromitacjach. Kto nie pogodzi się z tą oczywistą prawdą, skończy jak bohater Pożegnania Falkenberg (reż. Jesper Ganslandt, Dania, Szwecja 2006, s. 149-150).

Pewnego razu wspomniany już wcześniej Holden z Buszującego w zbożu zastanawia się nad istotą wspomnień. Kroczy przez park i duma: „Niektóre rzeczy powinny by zostawać zawsze nie zmienione. Żeby można je wpakować do jednej $z$ tych wielkich oszklonych szafi tak je przechowywać. Wiem, że to niemożliwe, ale szkoda". Faktycznie, to brzmi jak wygodne rozwiązanie - uśmiercić wspomnienia, nabić je na szpilki i niczym motyle włożyć w przeszklony pojemnik, by czasem, będąc tkniętym przez niejasny afekt, odwiedzać własne muzeum wspomnień.

6. Zob. Oskar Kokoschka, Die Träumenden Knaben, Kurt Wolff, Leipzig 1917. 
Karolina Kostyra rozważa tę możliwość w zwieńczeniu prowadzonych rozważań. Po opuszczeniu szałasów i letnisk czas dzieciństwa się kończy. Być może najprościej byłoby porzucić dawne marzenia, zamknąć je w szklanym kloszu i zacząć żyć „normalnie”? Autorka Wiosennej bujności traw proponuje inne rozwiązanie. Czas dorastania jest żywy, ale i ożywiany może być wciąż na nowo. Rolę pretekstu kolejnych reminiscencji odgrywa przecież kinematografia, wyzwalająca dawno zapomniane emocje, przywołująca dziecięce punkty widzenia i odnawiająca niegdysiejsze doznania. Pięknie jest oglądać motyle na żywo i przyjemnie jest się oddawać tęsknocie za motylami, które dawno temu odeszły. Podczas lektury książki Kostyry przypominają się kusicielskie namowy duchów przyrody ze Skradzionego dziecka. Wiosenna bujność traw jest książką tak żywą i domagającą się osobistego zaangażowania, że momentami chciałoby się dać porwać uwodzicielskim nimfom $z$ leśnych zakątków. Namysł nad przygodami z nastoletnich czasów rozrasta się ostatecznie do formy humanistycznej refleksji nad naturą rzeczywistości. Karolina Kostyra jest w swoich rozważaniach tak konsekwentnie sugestywna, że podczas lektury coraz silniej zdaje się wybrzmiewać w wyobraźni czytelnika propozycja, by „pozostać w starym, rodzinnym mieście” - jak wykrzykiwali Ramones w utworze Nie chcę dorastać. 